\title{
Pengaruh Kompetensi, Budaya Organisasi Terhadap Kinerja Karyawan Dengan Komitmen Organisasi Sebagai Variabel Intervening Pada PT PAG
}

\author{
Buyung Satria Permana ${ }^{1}$ Marbawi $^{2}$, Ibrahim Qamarius ${ }^{3}$ \\ ${ }^{123}$ Program Pascasarjana Ilmu Manajemen Universitas Malikussaleh \\ Email : buyung.181100410027@mhs.unimal.ac.id, marbawi@unimal.ac.id, \\ iqindo@gmail.com
}

\begin{abstract}
This study aims to determine the influence of competence and organizational culture through organization commitmen and its impact on employee performance to the PT. Perta Arun Gas of Lhokseumawe Regency. The data used is primary data by distributing questionnaires to 67 employees of the PT. Perta Arun Gas of Lhokseumawe Regency. Data analysis method used is path analysis and processed with the help of Statistical Package for Social Science (SPSS) application program. The result of the research shows that there is influence of competence and organizational culture to organization commitmen, and there is also influence of competence and organizational commitment toward employee performance, however organization culture is not influuence of employee performan PT. Perta Arun Gas of Lhokseumawe Regency. Furthermore, the results of the study found that organization commitmen variables mediate the absolute (full mediation) relationship of competence to the employee performance at the PT. Perta Arun Gas of Lhokseumawe Regency.
\end{abstract}

Keywords : Competence, Organization Culture, Organizational Commitment and Employee Performance.

\section{Pendahuluan}

Persoalan kinerja karyawan menjadi perhatian manajemen PT Perta Arun Gas (PT PAG) Lhokseumawe, dimana ditengah bisnis yang sedang beroperasi (di bidang Regasifikasi dan LNG Hub), mengoperasikan aset eks kilang PT Arun yang telah berumur lebih dari 40 tahun, dan penambahan bisnis baru (Cooldown Service dan pengoperasian LPG Plant), kinerja karyawan PT Perta Arun Gas justru mengalami penurunan selama 2 tahun terakhir (2018-2019) dengan adanya sejumlah karyawan yang resign. Turn over pekerja (laporan terintegrasi PT PAG, 2018 \& 2019) sebagai berikut :

Tabel 1.1

Turn Over Karyawan PT PAG LHOKSEUMAWETahun 2018-2019

\begin{tabular}{|c|c|c|}
\hline Tahun & Jumlah Pekerja & Penurunan dari tahun sebelumnya \\
\hline 2018 & 209 & 35 orang $(14,35 \%)$ \\
\hline 2019 & 192 & 17 orang $(8 \%)$ \\
\hline
\end{tabular}

Rencana penambahan bisnis baru seharusnya diiringi dengan bertambahnya jumlah karyawan melalui rekrutmen. Apabila terdapat sejumlah karyawan yang resign, perusahaan harus mengeluarkan waktu dan biaya untuk rekrutmen dan pelatihan karyawan baru tidak dapat langsung menempati posisi vacant yang ditinggal oleh karyawan yang resign. Potensi penurunan jumlah karyawan secara terus menerus di tahun yang akan datang tentunya berdampak langsung terhadap kinerja. Kinerja 
karyawan yang tinggi akan berdampak langsung terhadap perusahaan, maka perhatian pihak manajemen perusahaan tertuju bagaimana meningkatkan kinerja karyawan. Agar kinerja karyawan sesuai yang diharapkan maka berbagai komponen dan faktor lain yang mempengaruhi kinerja karyawan salah satunya adalah kompetensi.

Kompetensi mempunyai peranan yang sangat penting, karena pada umumnya kompetensi menyangkut kemampuan dasar sesorang untuk melakukan suatu pekerjaan. Kompetensi menjelaskan apa yang dilakukan karyawan di tempat kerja yang dilandasi pengetahuan dan keterampilan yang diperlukan karyawan serta didukung oleh sikap kerja yang dituntut oleh pekerjaan tersebut (Wibowo, 2007). PT PAG LHOKSEUMAWEtelah berusaha mengembangkan kompetensi dan keahlian karyawan yang dilaksanakan secara berkesinambungan melalui pelatihan. Program pelatihan diselenggarakan untuk meningkatkan keahlian maupun kompetensi dari karyawan sesuai dengan tuntutan pekerjaan dan kebutuhan perusahaan. Berikut data jumlah karyawan yang mendapat pelatihan selama tahun 2019 (laporan terintegrasi PT PAG, 2019).

Tabel 1.2

Karyawan yang Mendapatkan Pelatihan Selama Tahun 2019

\begin{tabular}{|c|c|c|c|}
\hline Pria & Wanita & $\begin{array}{c}\text { Jumlah Karyawan yang } \\
\text { Mendapatkan Pelatihan }\end{array}$ & $\begin{array}{c}\text { Total keseluruhan } \\
\text { Karyawan Tahun 2019 }\end{array}$ \\
\hline 81 & 8 & 90 & 192 \\
\hline
\end{tabular}

Berdasarkan data tersebut, selama tahun 2019 jumlah karyawan yang mendapatkan pelatihan sebanyak 90 karyawan dari total 192 karyawan. Hal ini mengindikasikan pada tahun tersebut belum meratanya karyawan yang mendapatkan pelatihan. Sehingga program pelatihan yang diselenggarakan untuk meningkatkan keahlian maupun kompetensi dari karyawan sesuai dengan tuntutan pekerjaan dan kebutuhan perusahaan belum optimal. Kurangnya pelatihan yang diperoleh akan membuat karyawan kurang yakin dalam melakukan tugas dan fungsinya sehingga dapat mempengaruhi kinerjanya. Karyawan yang telah mendapatkan pelatihan akan memiliki kompetensi sehingga mampu meningkatkan kinerjanya. Kinerja karyawan juga akan semakin meningkat apabila didukung oleh budaya organisasi.

Suatu organisasi memerlukan adanya budaya organisasi yang kuat dan dipahami secara mendalam agar diterapkan dan diperjuangkan oleh para karyawan sehingga kinerja organisasi/perusahaan dapat tercapai dengan optimal. Hakim (2015) menyatakan bahwa budaya organisasi memiliki hubungan linier dengan kinerja, sehingga semakin baik budaya organisasi akan diikuti dengan peningkatan kinerja karyawan. Sebagaimana diketahui bahwa SDM PT PAG Lhokseumawe mayoritas ex karyawan PT Arun. Kemudian budaya organisasi PT Arun dengan PT PAG Lhokseumawe tentu saja berbeda. Dalam melaksanakan dan menyelenggarakan usahanya, PT PAG Lhokseumawe menerapkan budaya organisasi yang telah ditetapkan oleh PT Pertamina (Persero) yaitu 6C: Clean (Bersih), Competitive (Kompetitif), Confident (Percaya diri), Customer Focus (Fokus pada pelanggan), Commercial (Komersial) dan Capable (Berkemampuan).

Untuk mengatasi inkonsisten hasil-hasil penelitian terdahulu diperlukan pendekatan kontinjensi (Govindarajan, 1986 dalam Hustanarina dan Nor, 2007) yaitu dengan cara memasukan variabel lain yang mungkin mempengaruhi hubungan kompetensi dan budaya organisasi dengan kinerja. Variabel yang diperkirakan dapat 
mempengaruhi hubungan kompetensi dan budaya organisasi dengan kinerja adalah komitmen organisasi. Rumasukun et al. (2015) menyatakan komitmen organisasi merupakan variabel mediasi pengaruh kompetensi karyawan terhadap kinerja, kompetensi karyawan kuat akan berpengaruh terhadap komitmen organisasi yang lebih tinggi, dan komitmen organisasi yang lebih tinggi dapat meningkatkan kinerja karyawan.

Dalam menyikapi perkembangan visi perusahaan untuk bisnis ke depan, diperlukan penambahan SDM yang berkualitas serta memiliki loyalitas pada perusahaan. Namun sepanjang tahun 2019, masih terdapat karyawan PT PAG LHOKSEUMAWEyang mengundurkan diri (resign) sehingga hubungan komitmen dengan kinerja karyawan penting untuk diteliti.

\section{Tinjauan Pustaka}

\section{Teori kompetensi}

Susanto (2016) kompetensi merupakan gabungan dari pengetahuan, kemampuan, kecakapan, sifat, sikap, apresiasi, pemahaman, 4dan harapan yang mendasari karakteristik seseorang untuk berunjuk kerja dalam menjalankan pekerjaan atau tugas guna mencapai standar kualitas karyawan dalam pekerjaan nyata.

\section{Teori budaya organisasi}

Schein (2010) memberi definisi bahwa budaya adalah suatu pola asumsi dasar yang ditemukan dan dikembangkan oleh suatu kelompok tertentu dalam suatu proses pembelajaran mengenai permasalahan integrasi internal dan integrasi eksternal, yang telah berhasil dengan cukup baik untuk dipertimbangkan sebagai sesuatu yang benar dan kemudian diajarkan kepada anggota baru sebagai sesuatu yang benar untuk diterima, dipikirkan sehubungan dengan permasalahan-permasalahan tersebut eori tentang komitmen organisasi

Pendapat para ahli Luthans (2011) komitmen organisasi adalah sikap yang mencerminkan loyalitas karyawan pada perusahaan atau organisasi dan proses berkelanjutan dimana anggota organisasi mengekresikan perhatiannya terhadap organisasi dan keberhasilan serta kemajuan yang berkesinambungan. Pendapat lain mengatakan komitmen organisasi didefinisikan sebagai keterlibatan individu/anggota organisasi di dalam organisasi.

\section{Teori tentang kinerja karyawan}

Menurut Wirawan (2009) kinerja (performance) adalah output yang dihasilkan oleh indikator atau fungsi suatu profesi atau pekerjaan dalam waktu tertentu. Menurut Rivai (2013) kinerja merupakan perilaku nyata yang ditampilkan setiap orang sebagai prestasi kerja yang dihasilkan oleh karyawan sesuai dengan perannya dalam perusahaan.

\section{Kerangka Konseptual}

Kerangka berfikir ini disusun atas dasar pemikiran dari penelitian berdasarkan dari fakta-fakta, observasi dan telaah penelitian. Kerangka pikir memuat teori, dalil atau konsep-konsep yang akan dijadikan dasar dalam penelitian. Hubungan antar-antar varibel yang digunakan dalam penelitian ini dapat dilihat pada Gambar 1 dibawah ini 


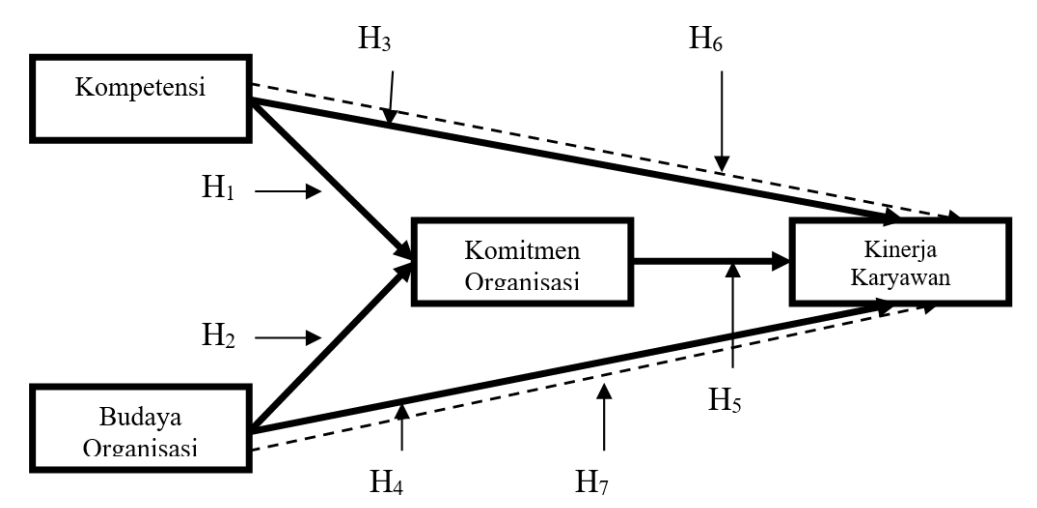

Gambar 1.1. Kerangka Konseptual

\section{Hipotesis Penelitian}

Hipotesis penelitian disusun untuk mencari fakta yang harus dikumpulkan, hipotesis adalah suatu pertanyaan sementara atau dugaan yang paling memungkinkan yang masih harus dicari kebenarannya, berdasarkan kerangka pemikiran diatas dan penelitian yang dilakukan oleh beberapa peneliti terdahulu maka dapat disusun sebuah hipotesis sebagai berikut :

$\mathrm{H}_{1}=$ Diduga terdapat pengaruh positif dan signifikan kompetensi terhadap komitmen organisasi karyawan pada PT PAG Lhokseumawe.

$\mathrm{H}_{2}=$ Diduga terdapat pengaruh positif dan signifikan budaya organisasi terhadap komitmen organisasi karyawan pada PT PAG Lhokseumawe.

$\mathrm{H}_{3}=$ Diduga terdapat pengaruh positif dan signifikan kompetensi terhadap kinerja karyawan pada PT PAG Lhokseumawe.

$\mathrm{H}_{4}=$ Diduga terdapat pengaruh positif dan signifikan budaya organisasi terhadap kinerja karyawan pada PT PAG Lhokseumawe.

$\mathrm{H}_{5}=$ Diduga terdapat pengaruh positif dan signifikan komitmen organisasi terhadap kinerja karyawan pada PT PAG Lhokseumawe.

$\mathrm{H}_{6}=$ Diduga komitmen organisasi memediasi hubungan antara komptensi dengan kinerja karyawan pada PT PAG Lhokseumawe.

$\mathrm{H}_{7}=$ Diduga komitmen organisasi memediasi hubungan antara budaya organisasi dengan kinerja karyawan pada PT PAG Lhokseumawe.

\section{Metode Penelitian.}

\section{Lokasi Penetian}

Adapun yang menjadi lokasi dalam penelitian ini adalah karyawan PT PAG, sedangkan yang menjadi objek dalam penelitian ini adalah seluruh karyawan PT. PAG Lhokseumawe.

\section{Populasi dan Sampel Penelitian \\ Populasi}

Populasi dalam penelitian ini merupakan wilayah generalisasi yang terdiri atas obyek/subyek yang mempunyai kualitas dan karakteristik tertentu yang ditetapkan oleh peneliti untuk di pelajari dan kemudian ditarik kesimpulanya, jadi populasi dalam penelitian ini adalah seluruh karyawan PT. PAG Lhokseumawe sebanyak 192 karyawan.

\section{Sampel}

Teknik pengambilan sampel dalam penelitian ini dillakukan dengan metode 
simple random sampling yaitu teknik penarikan sampel ini dilakukan dengan cara acak sederhana dari jumlah populasi untuk dijadikan sample yaitu sebanyak 67 orang karyawan pada PT. Perta Arun Gas (PAG) Lhokseumawe, adapun langkah pertama menetapkam ukuran sampel di hitung dengan rumus Slovin, yaitu :

$$
n=\frac{N}{1+N(e)^{2}}
$$

Maka ukuran sampel dalam penelitian ini :

$$
\begin{gathered}
n=\frac{192}{1+192(0,1)^{2}} \\
n=\frac{192}{2,92}
\end{gathered}
$$




$$
n=65,75
$$

Berdasarkan rumus di atas maka jumlah sampel dalam penelitian ini berjumlah 67 responden setelah dibulatkan.

\section{Teknik Pengumpulan Data}

Sumber data yang diperlukan kuesioner yaitu data primer, maka teknik pengumpulan data yang digunakan dalam penelitian ini adalah menggunakan angket atau kuesioner adalah suatu alat pengumpulan data yang berupa serangkaian pertanyaan yang diajukan tertulis yang diajukan kepada subyek untuk mendapatkan jawaban secara tertulis dari karyawan PT PAG tentang "Pengaruh Kompetensi dan Budaya Organisasi Terhadap Kinerja Karyawan dengan Komitmen Organisasi sebagai Variabel Intervening pada PT Perta Arun Gas Lhokseumawe".

\section{Operasional Variabel}

Tabel 1.3 Definisi Variabel dan Indikator

\begin{tabular}{|c|c|c|c|c|}
\hline No & Variabel & Definisi Variabel & Indikator & $\begin{array}{l}\text { Skala } \\
\text { Ukur }\end{array}$ \\
\hline 1. & $\begin{array}{l}\text { Kompetensi } \\
\qquad\left(\mathrm{X}_{1}\right)\end{array}$ & $\begin{array}{l}\text { Kemampuan, keahlian } \\
\text { dan pengalaman } \\
\text { karyawan pada PT Perta } \\
\text { Arun Gas Lhokseumawe. }\end{array}$ & $\begin{array}{ll}\text { 1. } & \text { Keyakinan } \\
\text { 2. Keterampilan } \\
\text { 3. Pengalaman } \\
\text { 4. Motivasi kerja } \\
\text { 5. Kepribadian } \\
\text { 6. Kemampuan } \\
\text { (Wibowo, 2016) }\end{array}$ & Likert \\
\hline 2 & $\begin{array}{l}\text { Budaya Organisasi } \\
\qquad\left(\mathrm{X}_{2}\right)\end{array}$ & $\begin{array}{l}\text { Nilai-nilai yang dipahami } \\
\text { bersama karyawan pada } \\
\text { PT Perta Arun Gas } \\
\text { Lhokseumawe. }\end{array}$ & 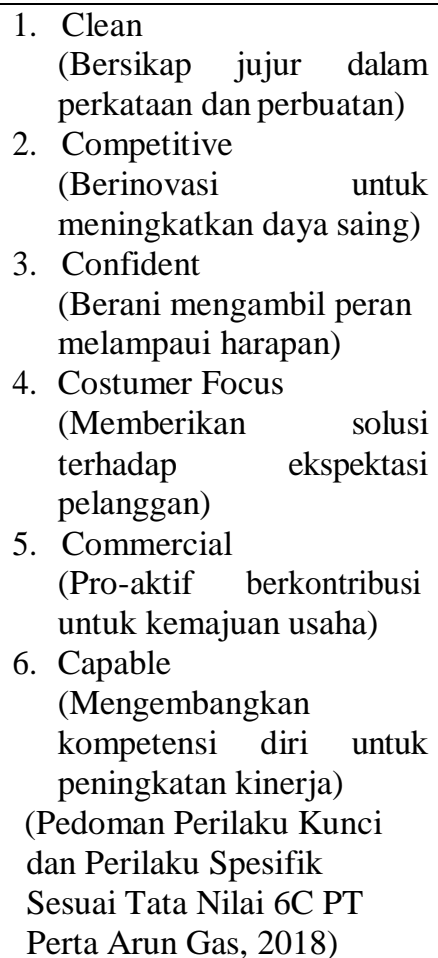 & Likert \\
\hline 3. & $\begin{array}{l}\text { Komitmen } \\
\text { Organisasi } \\
\quad\left(\mathrm{Y}_{1}\right)\end{array}$ & $\begin{array}{l}\text { Komitmen yang } \\
\text { ditunjukan karyawan } \\
\text { berupa integritas dan } \\
\text { loyalitas pada PT Perta } \\
\text { Arun Gas Lhokseumawe. }\end{array}$ & $\begin{array}{l}\text { 1. Setia dengan perusahaan } \\
\text { 2. Menjaga kerahasian } \\
\text { 3. Mentaati peraturan } \\
\text { 4. Rela bekorban } \\
\text { 5. Bekerja sama } \\
\text { 6. Memberi saran perbaikan } \\
\text { (Sopiah, 2008) }\end{array}$ & Likert \\
\hline
\end{tabular}




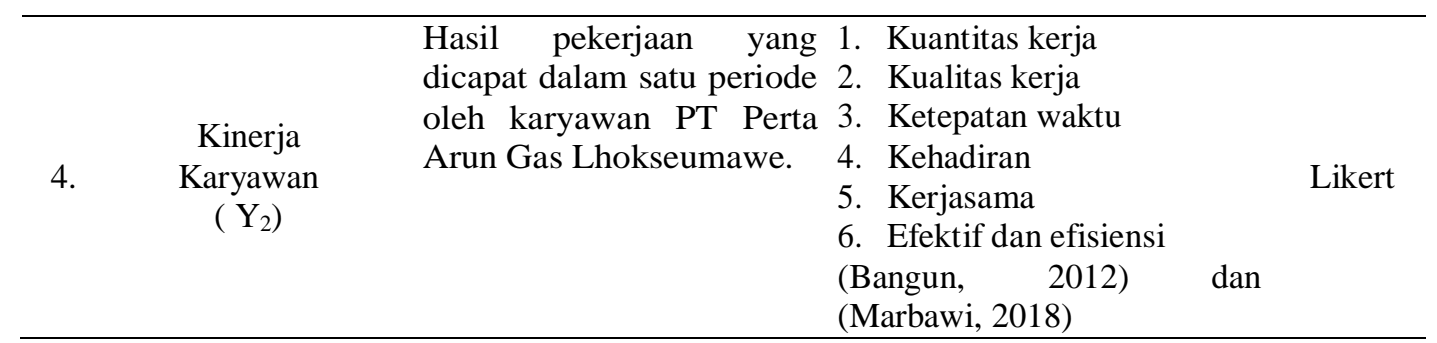

\section{Teknik Analisis Data}

Teknik analisis data dalam penelitian ini dilakukan melalui bantuan komputer dengan program SPSS (Statistical Package for Social Science). Metode yang digunakan untuk mengetahui bagaimana pengaruh antar variabel prediktor (independen/ekogen) dan variabel terikat (dependen/endogen) digunakan analisis model path analisys, analisis data dengan menggunakan bantuan program SPSS terdiri dari dua langkah, pertama adalah analisis substruktur satu dan kedua, untuk analisis substruktur 2 adalah sebagai berikut :

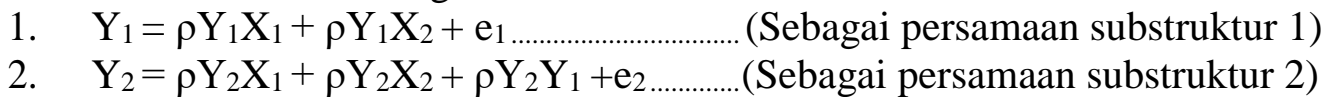

\section{B. Analisis dan Pembahasan}

\section{a. Gambaran Umum}

Pada tanggal 18 Maret 2013 ditetapkan sebagai tanggal berdirinya PT Perta Arun Gas sebagai perusahaan yang bergerak dibidang LNG Receiving and Regasification Terminal dan usaha-usaha lainnya yang menunjang. Pendirian PT Perta Arun Gas merupakan tindaklanjut dari Surat Kementerian BUMN melalui Surat Menteri Negara BUMN No. S-141/MBU/2012, yang salah satunya berisi tentang Proyek Revitalisasi Terminal LNG Arun. Dalam surat tersebut, PT Pertamina (Persero) diminta segera melaksanakan proyek revitalisasi LNG Arun yang diintegrasikan dengan pemipaan dari Arun ke Sumatra Utara dan memenuhi komitmen batas waktu penyelesaian proyek, yaitu pada akhir 2013.

Pada tanggal 02 Agustus 2013, PT Pertamina (Persero) melakukan novasi EPC kontrak proyek Arun LNG Receiving Hub and Regasification Terminal kepada PT Perta Arun Gas yang selanjutnya bertindak secara penuh dalam melaksanakan dan menyelesaikan proyek tersebut. Untuk mendukung aktivitas konstruksi Arun Regas dan terkait penggunaan beberapa asset existing eks PT Arun, maka PT Pertamina (Persero) telah mendapat surat dari Menteri Keuangan No. S-462/MK.06/2010 tanggal 28 Desember 2010 perihal Pemanfaatan Kilang LNG Arun sebagai Terminal Regasifikasi. Pada tanggal 27 Januari 2015, proyek berhasil menyelesaikan Mechanical Completion dan pada tanggal 19 Februari 2015 merupakan penerimaan kargo LNG pertama milikPT PLN (Persero) yang bersumber dari lapangan BP Tangguh di Provinsi Papua Barat. Selanjutnya, pada tanggal 30 Januari 2015, dilakukan kerjasama dengan afiliasi Pertamina dalam hal Pengelolaan Pelabuhan Blang Lancang dengan PT Pertamina Trans Kontinental.

Pada tanggal 09 Maret 2015, Presiden Republik Indonesia Joko Widodo meresmikan operasional PT Perta Arun Gas di Lhokseumawe sebagai Terminal Regasifikasi LNG. Selanjutnya, dilakukan pengiriman gas perdana ke anchor buyer Arun Regas dalam hal ini Pembangkit Listrik PLN Belawan pada tanggal 14 Maret 2015. PT Perta Arun Gas yang berlokasi di Area KEK Lhokseumawe mendapatkan pengesahan dari Menteri Keuangan mewakili Presiden Republik Indonesia melalui izin dari Keputusan Menteri Keuangan Republik Indonesia Nomor 1693/KM.4/2016 
tentang Penetapan Tempat Sebagai Pusat Logistik Berikat dan Pemberian Izin Penyelenggara Pusat Logistik Berikat Sekaligus Izin Pengusaha Pusat Logistik Berikat tanggal 18 September 2016.

Sesuai dengan arahan dari PT Pertamina melalui PT Pertamina Gas untuk mengakomodir kebutuhan LNG pada sektor tambang dan sektor komersial lainnya

khusus di wilayah Sumatera Bagian Utara, Perusahaan melakukan kerjasama dengan PT Pertamina Gas perihal Pembangunan dan Pengoperasian Fasilitas Pengisian LNG di Area Kilang LNG Arun yang ditandatangani tanggal 01 November 2016.

\section{Hasil Penelitian}

b. Asumsi Klasik

Uji asumsi klasik bertujuan untuk menguji apakah dalam model regresi variabel pengganggu atau residual memiliki distribusi norma, mulikolinieritas dan heteroskedastisitas, berikut ini uji asumsi klasik sebagai berikut :

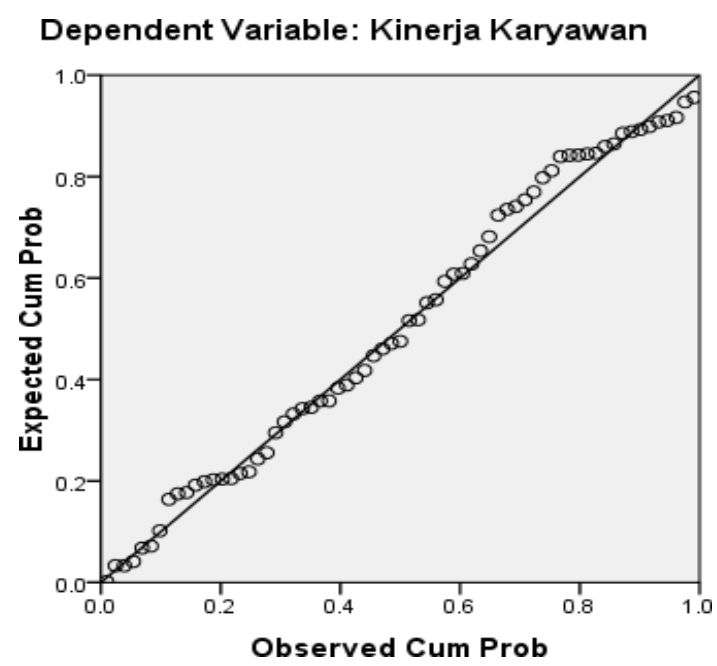

\section{Gambar 1.2. Hasil Uji Normalitas Normal P-P Plot}

Berdasarkan Gambar 1.2 dapat dijelaskan bahwa terlihat titik-titik menyebar berhimpit disekitar garis diagonal dan cendrung mengikuti arah garis diagonal sehingga dapat disimpulkan bahwa data yang digunakan dalam penelitian ini menunjukkan indikasi atau tergolong normal.

Tabel 1.4

Hasil Uji Multikolinearitas

\begin{tabular}{llcc}
\hline & \multicolumn{2}{c}{ Model } & \multicolumn{2}{c}{ Collinearity Statistics } \\
& & Tolerance & VIF \\
\hline 1 & (Constant) & 0.602 & 1.661 \\
& Kompetensi & 0.609 & 1.643 \\
& Budaya Organisasi & 0.709 & 1.409 \\
\hline
\end{tabular}

Berdasarkan hasil pengolahan pada Tabel 1.4 dapat dilihat bahwa nilai VIF untuk masing-masing variabel adalah $<10$ dan tolerance value tidak kurang dari 0,1 . Hal ini membuktikan bahwa model regresi yang digunakan dalam penelitian ini tidak terdapat gejala multikolinearitas. 


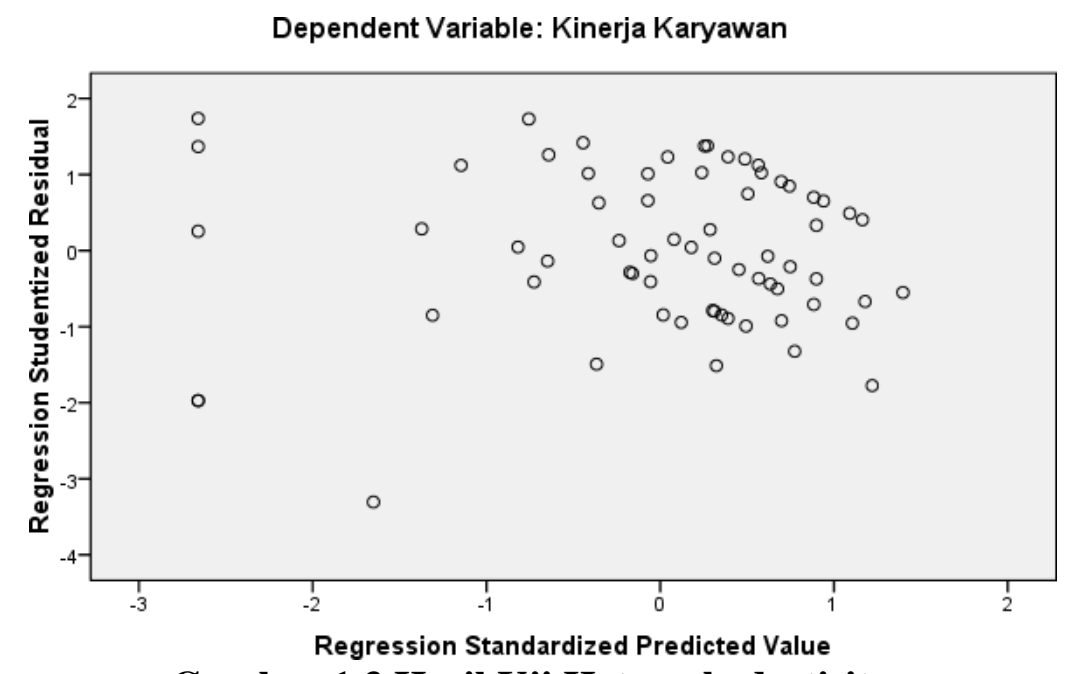

Gambar 1.3 Hasil Uji Heteroskedastisitas

Berdasarkan grafik scatterplots Gambar 1.3 dapat diketahui bahwa sebaran titiktitik yang acak baik di atas atau di bawah angka 0 dari sumbu Y. Hal ini dapat disimpulkan bahwa tidak terjadi heteroskedastisitas dalam model regresi sehingga model regresi layak dipakai untuk memprediksi kinerja karyawan berdasarkan variabel independen kompetensi, budaya organisasi, komitmen organisasi dan kinerja karyawan, berikut ini hasil analisis jalur seperti gambar dibawah ini.

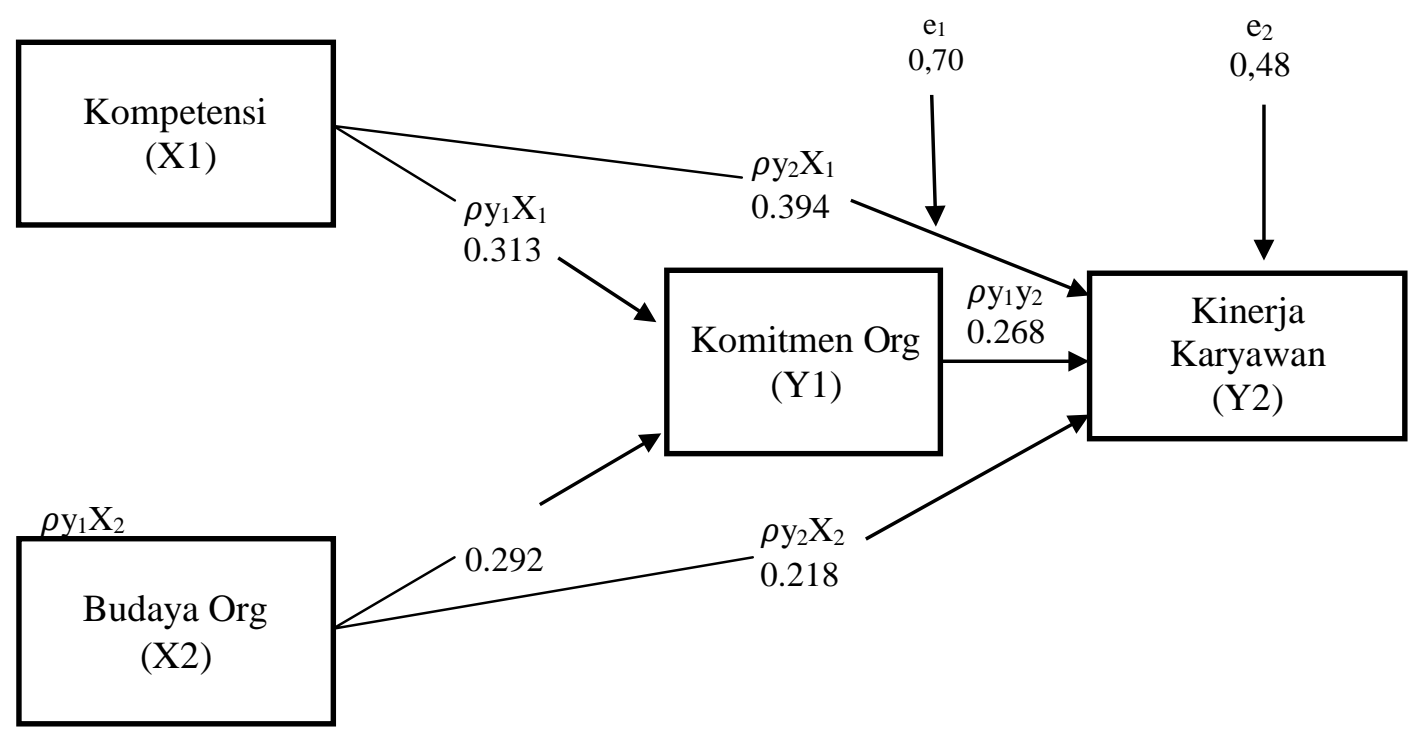

Gambar 1.4. Model Analisis Jalur (Path nalysis) 


\section{c. Analisis Jalur (Path Analisys) Persamaan Pertama}

Kerja.

Pengaruh Pendidikan dan Pelatihan Secara Bersama-sama terhadap Motivasi

Uji koefisien determinasi ( $\mathrm{R}$ square) digunakan untuk mengukur seberapa jauh kemampuan model dalam menerangkan variasi variabel dependen untuk hipotesis pengaruh kompetensi dan budaya organisasi terhadap komitmen organisasi. Berdasarkan estimasi regresi dengan program SPSS dapat dilihat pada Tabel 1.5 berikut.

Tabel 1.5 Koefisien Determinasi

\begin{tabular}{rcccc}
\hline Model & $R$ & $R$ Square & Adjusted R Square & Std. Error of the Estimate \\
\hline 1 & $0.539^{\mathrm{a}}$ & 0.291 & 0.268 & 3.55205 \\
\hline
\end{tabular}

Prediktor : Kompetensi dan Budaya Organisasi

Berdasarkan tabel diatas, hasil perhitungan dalam model summary didapatkan hasil besarnya angka $\mathrm{R}$ square $\left(\mathrm{R}^{2}\right)$ adalah adalah 0,291 yang artinya angka tersebut menunjukkan bahwa kompetensi dan budaya organisasi terhadap komitmen organisasi adalah sebesar $29,1 \%$, sedangkan sisanya $71,9 \%$ dipengaruhi oleh faktor lain. Dengan demikian, variabelitas komitmen organisasi yang dapat diterangkan dengan mengunakan variabel kompetensi dan budaya organisasi adalah sebesar 29,1\%, sedangkan pengaruh sebesar 71,9\% disebabkan oleh variabel-variabel di luar model ini. Pengujian pengaruh variabel bebas secara bersama-sama digunakan uji F. hasil perhitungan regresi secara simultan dapat dilihat Tabel 1.6.

Tabel 1.6 Hasil Analisis Regresi Simultan ( Uji F)

\begin{tabular}{|c|c|c|c|c|c|c|}
\hline \multicolumn{2}{|c|}{ Model } & Sum of Squares & $D f$ & Mean Square & $F$ & Sig. \\
\hline \multirow[t]{3}{*}{1} & Regression & 330.627 & 2 & 165.314 & 13.102 & $0.000^{\mathrm{a}}$ \\
\hline & Residual & 807.492 & 64 & 12.617 & & \\
\hline & Total & 1138.119 & 66 & & & \\
\hline
\end{tabular}

Predictor : Kompetensi dan Budaya Organisasi

Dependent : Komitmen Organisasi

Hasil analisis statistik menunjukkan nilai Uji $F_{\text {hitung }}$ sebesar 13.102 dengan tingkat signifikansi pada 0,000. Karena probabilitas jauh lebih kecil dari 0,05 maka model regresi dapat digunakan untuk memprediksi komitmen organisasi atau variabel kompetensi dan budaya organisasi secara simultan berpengaruh terhadap komitmen organisasi, hal ini disebabkan oleh karena tingkat signifikansi $0.000<0,05$. Dengan demikian, variabel dalam penelitian ini telah memenuhi persyaratan goodness of fit suatu model path analisis. Tabel 1.6 di atas dapat disimpulkan bahwa kompetensi dan budaya organisasi secara bersama-sama mempengaruhi komitmen organisasi.

\section{Pengaruh kompetensi dan budaya organisasi secara parsial terhadap komitmen organisasi}

Untuk melihat besarnya pengaruh variabel kompetensi dan budaya organisasi terhadap komitmen organisasi secara parsial, digunakan uji t, sedangkan untuk melihat besarnya pengaruh, digunakan angka beta atau Standardized Coeffecient di seperti Tabel 1.7 dibawah ini : 
Tabel 1.7 Analisis Jalur Persamaan 1

\begin{tabular}{llccccc}
\hline \multirow{2}{*}{ Model } & & \multicolumn{2}{c}{$\begin{array}{c}\text { Unstandardized } \\
\text { Coefficients }\end{array}$} & $\begin{array}{c}\text { Standardized } \\
\text { Coefficients }\end{array}$ & $\mathrm{t}$ & \multirow{2}{*}{ Sig. } \\
\cline { 3 - 5 } & & B & Std. Error & Beta & & \\
\hline 1 & (Constant) & 6.232 & 2.469 & & 2.524 & 0.014 \\
& Kompetensi & 0.338 & 0.140 & 0.313 & 2.413 & 0.019 \\
& Budaya & 0.314 & 0.140 & 0.292 & 2.245 & 0.028 \\
\hline
\end{tabular}

Dependent : Komitmen Organisasi

a. Pengaruh antara kompetensi terhadap komitmen organisasi

Hasil analisis jalur persaman pertama diperoleh angka $t_{\text {hitung }}$ dalam penelitian sebesar 2.414 Taraf signifikansi 0,05 dengan derajat kebebasan (DK) dengan ketentuan $\mathrm{DK}=67-3=64$, dari ketentuan tersebut diperoleh angka $t$ tabel sebesar 1,998, berdasarkan hasil perhitungan, diperoleh angka $t_{\text {hitung }}$ penelitian sebesar $2.413>\mathrm{t}$ tabel sebesar 1,998 sehingga hipotesis 1 diterima. Artinya, terdapat pengaruh antara kompetensi terhadap komitmen organisasi karyawan PT. PAG Lhokseumawe.

b. Pengaruh antara budaya organisasi dan komitmen organisasi

Hasil analisis jalur persaman pertama diperoleh angka $t_{\text {hitung }}$ dalam penelitian sebesar 2.245 taraf signifikansi 0,05 dengan derajat kebebasan (DK) dengan ketentuan $\mathrm{DK}=67-3=64$, dari ketentuan tersebut diperoleh angka $\mathrm{t}$ tabel sebesar 1,998, berdasarkan hasil perhitungan, diperoleh angka $t_{\text {hitung }}$ penelitian sebesar $2.245>\mathrm{t}$ tabel sebesar 1,998 sehingga hipotesis 2 diterima. Artinya, terdapat pengaruh antara budaya organisasi terhadap komitmen organisasi karyawan PT. PAG Lhokseumawe.

\section{d. Analisis Jalur (Path Analisys) Persamaan Kedua.}

Pengaruh kompetensi, budaya organisasi dan komitmen organisasi terhadap kinerja karyawan, hasil analisis koefisien determinasi ( $\mathrm{R}$ square) digunakan untuk mengukur seberapa jauh kemampuan model dalam menerangkan variabel dependen untuk hipotesis pengaruh variabel bebas terhadap variabel terikat, dapat dilihatini.

Tabel 1.8 Koefisien Determinasi

\begin{tabular}{rcccc}
\hline Model & $R$ & $R$ Square & Adjusted $R$ Square & Std. Error of the Estimate \\
\hline 1 & $.730^{\mathrm{a}}$ & .533 & .510 & 2.89402 \\
\hline
\end{tabular}

a. Predictors: Kompetensi, Budaya Organisasi \& Komitmen Organisasi

Berdasarkan Tabel 1.8. perhitungan dalam model summary di dapatkan hasil angka $\mathrm{R}$ square adalah adalah 0,533 yang artinya angka tersebut menunjukkan bahwa variabel kompetensi, budaya organisasi dan komitmen organisasi dapat menjelaskan kinerja karyawan adalah sebesar 53.3\%, sedangkan sisanya $47.7 \%$ dijelaskan oleh faktor lain. Dengan demikian, variabilitas kinerja karyawan yang dapat diterangkan dengan mengunakan variabel kompetensi, budaya organisasi dan komitmen organisasi adalah sebesar 53,3\%, sedangkan sisanya sebesar $47.7 \%$ dijelaskan oleh variabelvariabel diluar model ini seperti motivasi dan pengembangan karir. Pengujian pengaruh variabel bebas secara simultan digunakan uji F. Hasil perhitungan regresi secara simultan dapat dilihat 1.9. dibawah ini. 
Tabel 1.9 Hasil Analisis Regresi Simultan (Uji F)

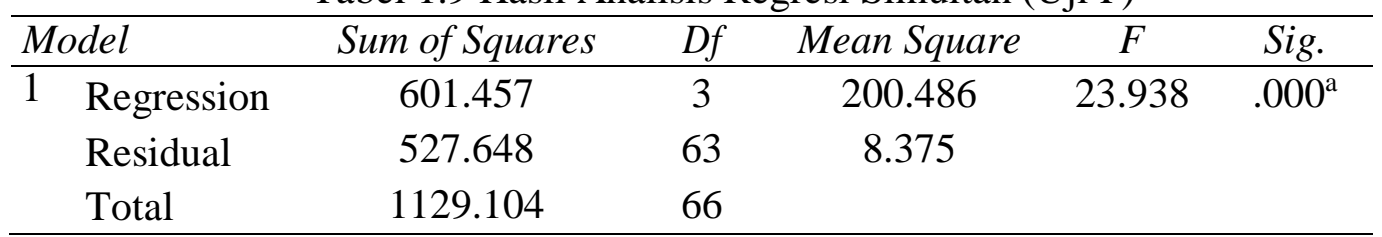

1. Predictors: Kompetensi, Budaya Organisasi \& Komitmen Organisasi

2. Dependent Variable: Kinerja Karyawan

Hasil analisis statistik menunjukkan nilai Uji $F_{\text {hitung }}$ sebesar 23.938 dengan tingkat signifikansi pada 0,000. karena probabilitas jauh lebih kecil dari 0,05 maka model regresi dapat digunakan untuk memprediksi kinerja karyawan atau dapat dikatakan bahwa variabel kompetensi, budaya organisasi dan komitmen organisasi secara simultan berpengaruh terhadap kinerja karyawan, di mana taraf signifikansi $0.000<0,05$ yang berarti bahwa variabel dalam penelitian ini sudah memenuhi syarat pemodelan goodnees of fit analis jalur, berikut ini analisis jalur persamaan kedua secara masing-masing adalah sebagai berikut :

\section{Pengaruh kompetensi, budaya organisasi dan komitmen organisasi secara parsial terhadap kinerja karyawan}

Selanjutnya untuk melihat besarnya pengaruh variabel kompetensi, budaya organisasi dan komitmen organisasi terhadap kinerja karyawan secara parsial, digunakan uji t seperti Tabel 1.10 di bawah ini.

Tabel 1.10 Hasil Analisis Jalur Persamaan 2

\begin{tabular}{|c|c|c|c|c|c|c|}
\hline \multirow[b]{2}{*}{ Mod } & & \multicolumn{2}{|c|}{$\begin{array}{c}\text { Unstandardized } \\
\text { Coefficients }\end{array}$} & \multirow{2}{*}{$\begin{array}{c}\text { Standardized } \\
\text { Coefficients } \\
\text { Beta }\end{array}$} & \multirow[b]{2}{*}{$t$} & \multirow[b]{2}{*}{ Sig. } \\
\hline & & $B$ & Std. Error & & & \\
\hline \multirow[t]{4}{*}{1} & (Constant) & 8.078 & 2.109 & & 3.830 & 0.000 \\
\hline & Kompetensi & 0.423 & 0.119 & 0.394 & 3.548 & 0.001 \\
\hline & Budaya Organisasi & 0.234 & 0.119 & 0.218 & 1.976 & 0.053 \\
\hline & Komitmen Organisasi & 0.267 & 0.102 & 0.268 & 2.618 & 0.011 \\
\hline
\end{tabular}

Dependent Variable: Kinerja Karyawan

\section{Pengaruh antara kompetensi terhadap kinerja karyawan}

Hasil analisis jalur persaman kedua diperoleh angka $t_{\text {hitung variabel kompetensi }}$ sebesar 3.548 Taraf signifikansi 0,05 dengan derajat kebebasan (DK) dengan ketentuan $\mathrm{DK}=67-3=64$, dari ketentuan tersebut diperoleh angka $t_{\text {tabel }}$ sebesar 1,998, berdasarkan hasil perhitungan, diperoleh angka $t_{\text {hitung }}$ penelitian sebesar $3.548>t$ tabel sebesar 1,998 sehingga hipotesis 3 diterima. Artinya, terdapat pengaruh antara kompetensi terhadap kinerja karyawan PT. PAG Lhokseumawe.

\section{Pengaruh antara budaya organisasi terhadap kinerja karyawan}

Hasil analisis jalur persaman kedua diperoleh angka $t_{\text {hitung }}$ dalam penelitian sebesar 1.976. Taraf signifikansi 0,05 dengan derajat kebebasa (DK) dengan ketentuan $\mathrm{DK}=67-3=64$, dari ketentuan tersebut diperoleh angka $\mathrm{t}$ tabel sebesar 1,998, berdasarkan hasil perhitungan, diperoleh angka thitung penelitian sebesar $1.976<\mathrm{t}$ tabel 
sebesar 1,998 sehingga hipotesis 4 ditolak. Artinya, tidak terdapat pengaruh antara budaya organisasi terhadap kinerja karyawan PT. PAG Lhokseumawe.

\section{Pengaruh komitmen organisasi terhadap kinerja karyawan}

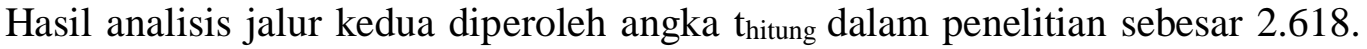
Taraf signifikansi 0,05 dengan derajat kebebasa (DK) dengan ketentuan DK= $67-3=$ 64, dari ketentuan tersebut diperoleh angka t tabel sebesar 1,998, berdasarkan hasil perhitungan, diperoleh angka $t_{\text {hitung }}$ penelitian sebesar $2.618>\mathrm{t}$ tabel sebesar 1,998 sehingga hipotesis 5 diterima. Artinya, terdapat pengaruh antara komitmen organisasi terhadap kinerja karyawan PT. PAG Lhokseumawe.

\section{Pengaruh kompetensi terhadap kinerja melalui komitmen organisasi}

Hasil pengujian efek mediasi (intervening) hubungan variabel kompetensi dengan variabel knerja karyawan yang dimediasi oleh variabel komitmen organisasi, untuk mengetahui signifikansi pada jalur c' dapat mengggunakan sobel test an interactive calculation tool for mediation tests yang menghasilkan Sobel test, Aroian test, dan Goodman test, dalam penelitian ini hasil test yang dipakai untuk melihat test statistic, standar error, dan p-value adalah angka atau nilai dari sobel test, namun dalam penelitian ini uji mediasi yang dilakukan jika semua jalur signifikan sehingga variable komitmen organisasi memenuhi syarat sebagai variable mediasi, maka nilai signifikansi untuk kesemua jalur (A, B dan C, ) signifikan dapat disimpulkan komitmen organisasi memediasi secara penuf (full mediation) dalam penelitian ini.

\section{Pengaruh budaya organisasi terhadap kinerja melalui komitmen organisasi}

Hasil pengujian efek mediasi (intervening) hubungan variabel budaya organisasi dengan variabel kinerja karyawan yang dimediasi oleh variabel komitmen organisasi, untuk mengetahui signifikansi pada jalur c' dapat mengggunakan sobel test an interactive calculation tool for mediation tests yang menghasilkan Sobel test, Aroian test, dan Goodman test. Dalam penelitian ini hasil test yang dipakai untuk melihat test statistic, standar error, dan p-value adalah angka atau nilai dari sobel test dengan menggunakan software ini secara online diketahui nilai signifikansi jalur C' berdasarkan hasil perhitungan nilai probabilitas untuk jalur c' dengan menggunakan Sobel Test maka nilai signifikansi untuk kesemua jalur (A dan B)signifikan sedangkan jalur $\mathrm{C}$ tidak signifikan, sehingga dalam model ini komitmen organisasi belum memenuhi syarat sebagai variabel mediasi

\section{Pembahasan}

\section{Pengaruh kompetensi terhadap komitmen organisasi}

Berdasarkan pengujian statistik variabel kompetensi terhadap komitmen organisasi dengan menggunakan analisis jalur, hasil penelitian ini mendukung penelitian Fadli dan Kartawijaya (2012) menyimpulkan kompetensi karyawan berpengaruh positif terhadap komitmen kerja, hal ini dapat ditunjukkan dengan nilai korelasinya yang tinggi yang berarti korelasinya positif (cukup kuat), dengan nilai koefisien determinasi sebesar baik. Penelitian ini membuktikan bahwa ada hubungan yang signifikan antara kompetensi karyawan terhadap komitmen kerja, dengan demikian kompetensi karyawan berpengaruh cukup kuat terhadap komitmen kerja, berdasarkan hasil penelitian sebelumnya dan pendapat para ahli terlihat bahwa hasil penelitian ini didukung oleh penelitian sebelumnya sehingga hipotesis 1 diterima sehingga hasil penelitian ini dapat membuktikan konsep sebelumnya. 


\section{Pengaruh budaya organisasi terhadap komitmen organisasi}

Hasil perhitungan diperoleh nilai $t$ hitung sebesar 2.394 dengan taraf signifikansi sebesar $0.019<0,05$ lebih besar sari t tabel yang berarti bahwa menerima hipotesis 2 . Artinya ada pengaruh antara budaya organisasi berpengaruh terhadap komitmen organisasi karyawan PT. PAG Lhokseumawe. Hasil penelitian ini mendukung panelitian Robbins (2013), Luthans (2011) menyatakan bahwa budaya organisasi sangat penting dalam perilaku organisasi dan dapat meningkatkan kominmen terhadap organisasi, menurut Gibson (2010) mengemukakan bahwa budaya organisasi turut menentukan prestasi kerja seseorang dapat meningkatkan komitmen dan kinerja. Hasil penelitian ini mendukung penelitian (Taurisa \& Ratnawati, 2012). dalam peneltian ini budaya organisasi yang paling mendominasi adalah perasaan dihargai, di mana hal ini menunjukkan bahwa ketika seorang karyawan merasa dihargai dalam sebuah organisasi, maka ketika itu pula tercipta kesepakatan yang tinggi dan dapat meningkatkan kinerja karyawan mengenai apa yang diyakini dalam sebuah organisasi, sehingga terbentuk nilai budaya untuk meningkatkan suatu komitmen organisasional dalam diri karyawan,(Taurisa \& Ratnawati, 2012).

\section{Pengaruh kompetensi terhadap kinerja karyawan}

Berdasarkan pengujian statistik variabel kompetensi terhadap kinerja karyawan dengan menggunakan analisis jalur, kompetensi berpengaruh terhadap kinerja karyawan PT. PAG Lhokseumawe, hasil analisis data yang dilakukan diperoleh nilai $\mathrm{t}$ hitung lebih bersar $\mathrm{t}$ tabel berarti bahwa menerima hipotesis 3 artinya terdapat pengaruh antara kompetensi terhadap kinerja karyawan PT. PAG Lhokseumawe. Pengujian secara statistik membuktikan bahwa pada kinerjakaryawan PT. PAG Lhokseumawe, di mana kinerja karyawan PT. PAG dapat dipengaruhi kompetensi hal ini disebabkan kompetensi yang dimiliki karyawan dalam kegiatan sehari-hari dapat meningkatkan kinerja karyawan PT. PAG Lhokseumawe. Hasil penelitian ini juga didukung penelitian Kartika (2014), Winanti (2011), Qamariah dan Fadli (2011), hasil penelitiannya konsep ini mendukung teori yang dikemukan oleh Gibson (1993).

\section{Pengaruh budaya organisasi terhadap kinerja karyawan}

Dari perhitungan statistik diperoleh nilai $t$ hitung lebih kecil $t$ tabel yang berarti bahwa menolak hipotesis 4. Artinya tidak ada pengaruh antara budaya organisasi tidak mempengaruhi terhadap kinerja karyawan PT. PAG Lhokseumawe. Hasil penelitian ini tidak mendukung penelitian yang pernah dilakukan Robbins (2013), Luthans (2011), Siahaan (2017) dan Marbawi (2018) yang menyatakan budaya organisasi berpengaruh positif dan signifikan tehadap kinerja karyawan, hasil penelitian terdahulu yang dilakukan, (Logahan et all., 2014) hasil riset bahwa budaya organisasi yang diterapkan pada perusahaan baik dan secara umum berarti karyawan dapat menerima dan mampu menjalankan budaya organisasi yang diterapkan dalam sebuah organisasi, keterlibatan kerja karyawan pada sebuah organisasi termasuk baik dan secara keseluruhan terdapat keberagaman nilai-nilai yang terlalu tinggi diantara para karyawan pada organisasi termasuk baik, berarti secara umum perusahaan membuat karyawannya nyaman dalam perusahaan dan jawaban mereka juga cenderung seragam. (Logahan et al., 2014).

\section{Pengaruh komitmen organisasi terhadap kinerja karyawan}

Melalui perhitungan yang telah dilakukan terdapat pengaruh signifikan komitmen organisasi terhadap kinerja karyawan PT. PAG Lhokseumawe diperoleh

nilai $t_{\text {hitung }}$ lebih besar dari $t_{\text {tabel }}$ yang berarti bahwa menerima hipotesis 5 . Artinya ada pengaruh antara komitmen organisasi terhadap kinerja karyawan PT. PAG 
Lhokseumawe. Besarnya pengaruh komitmen organisasi terhadap kinerja karyawan dapat dilihat pada bab sebelumnya, hasil penelitian mendukung penelitian sebelumnya, dimana komitmen organisasional menunjukkan suatu daya dari seseorang dalam mengidentifikasikan keterlibatannya dalam suatu bagian organisasi (Mowday, et al. dalam Vandenberg, dalam Trisnaningsih (2007) dan Sopiah (2008), Noor (2010), Robbins (2013) dan Luthans (2011) juga riset Meyer et al. (Suparyadi, 2015) menguji hubungan antara kinerja manajer tingkat atas dengan komitmen affective dan komitmen continuance pada perusahaan atau organisasi, hasil penelitian menyatakan bahwa komitmen affective berkorelasi secara positif dengan kinerja.

\section{Kesimpulan}

Berdasarkan analisis data dan pembahasan beberapa hal dapat disimpulkan sebagai berikut :

1. Kompetensi berpengaruh positif dan signifikan terhadap komitmen organisasi karyawan PT PAG, artinya apabila kompetensi karyawan PT PAG meningkat maka akan meningkatkan komitmen organisasi karyawan PT PAG.

2. Budaya organisasi berpengaruh positif dan signifikan terhadap komitmen organisasi karyawan PT PAG, artinya apabila pemahaman dan penerapan nilai budaya organisasi meningkat maka akan meningkatkan komitmen organisasi karyawan PT PAG.

3. Kompetensi berpengaruh positif dan signifikan terhadap kinerja karyawan PT PAG, artinya apabila kompetensi karyawan PT PAG meningkat maka akan meningkatkan kinerja karyawan PT PAG.

4. Budaya organisasi tidak berpengaruh terhadap kinerja karyawan PT PAG, artinya budaya organisasi belum dapat meningkatkan kinerja karyawan PT PAG.

5. Komitmen organisasi berpengaruh positif dan signifikan terhadap kinerja karyawan PT PAG, artinya apabila komitmen karyawan PT PAG meningkat maka akan meningkatkan kinerja karyawan PT PAG

\section{Daftar Pustaka}

Allen, N.J., dan Meyer, J.P. 1990. The measurement and antecedents of affective, continuance, and normative commitment to organization. Journal ofoccupational psychology.

Arifin, Noor 2010. Analisis Budaya Organisasional Terhadap Komitmen Kerja Karyawan Dalam Peningkatan Kinerja Organisasional Karyawan Pada Koperasi Bmt di Kecamatan Jepara, Jurnal ekonomi dan pendidikan, vol 8 No 2, November 2010

Bangun, Wilson. 2012. Manajemen Sumber Daya Manusia. Jakarta: PT Erlangga Fadli, U.M., Fadili, D.A., Kartawijaya, Y. 2012. Pengaruh Kompetensi Karyawan terhadap Komitmen Kerja pada PT PLN (persero) Rayon Rengasdengklok. Jurnal Manajemen, Vol. 9, No.2: 577-589

Gibson, Ivancevich, Donnely. 1993. Organisasi, perilaku, Struktur dan proses, Edisi Kelima, Cetakan Ketujuh Terjemahan Djarkasih. Jakarta: Penerbit Erlangga.

\section{Jakarta: Erlangga.} 2010. Organisasi, Perilaku, Struktur, Proses, Edisi Ke-

Hustanarina, F dan Nor, W. 2007. Pengaruh Keterlibatan Pekerjaan dan Budget Imphasis dalam Hubungan antara Partisipasi Anggaran dengan Senjangan Anggaran. The 1st Accounting Conference Faculty of Economic Universitas Indonesia.

Kartika, Lucia N 2014. Pengaruh Tingkat Kompetensi Terhadap Kinerja Pegawai 
Administrasi Perkantoran. Jurnal Ekonomi dan Bisnis Volume XVII No.1 Laporan Terintegrasi Tahun 2018 \& Tahun 2019 PT Perta Arun Gas

Logahan, J.M., \& Aesaria, S.M. 2014. Budaya organisasi dan keterlibatan kerja terhadap komitmen organisasi berdampak pada kinerja karyawan pada BTNciputat. Binus Bussiness Review, 5(2), 551-563

Luthans, Fred. 2011. Organizational Behavior (12th ed.). New York: McGraw-Hill.

Marbawi. 2017. The influence of individual characteristics and transformational leadership on job satisfaction and performance of employee in Bank Aceh Syaria, Proceding EBIC Universitas Sumatera Utara.

Mowday, R.T., R.M., Steers, \& L.W., Porter. 1979. "The Measurement of Organizational Commitment." Journal of Vacational Behavior, Vol. 14. 
Qamariah, Inneke dan Fadli. 2011. Pengaruh Perencanaan Dan Kompetensi Karyawan Terhadap Kinerja Karyawan Pada PT. Indonesia Asahan Alumunium Kuala Tanjung. Jurnal Ekonomi, 14(2): h:63-73.

\section{Prentice Hall.}

2013. Organizational Behavior (15th Ed.). New Jersey: Pearson

Rumasukun, S.F.A., Rante, Y., Wambrauw, O.O., Bharanti, B.E., 2015. The Influence of Human Resource Management Strategy and Competence on Employee Performance with the Mediation of Work Motivation, Organizational Commitment and Work Culture (Study at the Official of Management of Communication and Information Technology of Papua Province). International Journal of Business and Management Invention, 4 : 15-27.

Suparyadi, H. 2015. Manajemen Sumber Daya Manusia Menciptakan Keunggulan Bersaing Berbasis Kompetensi SDM. Yogyakarta: C.V Andi Offset.

Trisnaningsih, Sri. 2007. Independensi Auditor Dan Komitmen Organisasi Sebagai Mediasi Pengaruh Pemahaman Good Governance, Gaya Kepemimpinan Dan Budaya Organisasi Terhadap Kinerja Auditor. Unhas Makassar, 26-28 Juli 2007. Universitas Pembangunan Nasional "Veteran", Jawa Timur.

Schein, Edgar H.. 2010. Organizational Culture and Leadership. Fourth Edition. San Fransisco: Jossey-Bass A Wiley Imprint.

Siahaan, Elisabet, 2007. Anteseden Kinerja Karyawan dan Pengaruhnya Terhadap Kepuasan Kerja Karyawan: Studi Berdasarkan Perspektif Jender Pada Sektor Jasa Perbankan di Wilayah DKI Jakarta, Universitas Brawijaya Program Pascasarjana, Malang.

2017. The Antecedent of employee's performance and the influence on employee job satisfaction in Banking Service in Indonesia. Bank and Bank System, Vol 12 issue 4.

Sopiah, Dr, MM., M.Pd. 2008. Perilaku Organisasional. Yogyakarta: CV. Andi Offset.

Susanto, Ahmad. 2016. Manajemen Peningkatan Kinerja Guru. Jakarta: Prenadamedia Group.

Taurisa, C., M. \& Ratnawati, I. 2012. Analisis Pengaruh Budaya Organisasi dan Kepuasan Kerja terhadap Komitmen Organisasional dalam Meningkatkan Kinerja Karyawan (Studi pada PT. Sido Muncul Kaligawe Semarang). Jurnal Bisnis \& Ekonomi, 19(2).

Vandenberg, Robert, J., \& Charles, E.. 1992. "Examining The Causal Order of Job Satisfaction and Organizational Commitment." Journal of Management, March.

Wibowo. 2007. Manajemen Kinerja. Jakarta: PT. Raja Grafindo Parsada. 2016. Manajemen Kinerja edisi 5. Jakarta: PT. Raja Grafindo Parsada.

Winanti, Marlina Budhiningtias. 2011. Pengaruh Kompetensi Terhadap Kinerja Karyawan (Survei pada PT. Frisian Flag Indonesia Wilayah Jawa Barat). Majalah Ilmiah UNIKOM, 7(2): h:249-267.

Wirawan. 2009. Evaluasi Kinerja Sumber Daya Manusia Teori, Aplikasi dan Penelitian. Jakarta: Salemba Empat. 